\title{
SUSTAINABLE RHINO HORN PRODUCTION AT THE POINTY END OF THE RHINO HORN TRADE DEBATE
}

W. Andrew Taylor ${ }^{1,2,}{ }^{*}$, Dave Balfour ${ }^{3}$, D. Kirsty Brebner ${ }^{1}$, Rynette Coetzee ${ }^{1,4}$, Harriet DaviesMostert ${ }^{1,5}$, Peter A. Lindsey ${ }^{6,7}$, Jo Shaw', \& Michael 't Sas-Rolfes'?

${ }^{1}$ Endangered Wildlife Trust, Private Bag X11, Modderfontein 1645, Gauteng, South Africa, taylor.wa@gmail.com; corresponding author: taylor.wa@gmail.com, +27 732411256

${ }^{2}$ Centre for Veterinary Wildlife Studies, University of Pretoria, Private Bag X04, Onderstepoort 0110, South Africa

${ }^{3}$ Independent, Box 8348, Nahoon, East London 5210, South Africa

${ }^{4}$ Gauteng Department of Agriculture and Rural Development, Pretoria, South Africa

${ }^{5}$ Centre for Wildlife Management, University of Pretoria, Private Bag X20, Hatfield, Pretoria 0028, South Africa

${ }^{6}$ Mammal Research Institute, Department of Zoology and Entomology, University of Pretoria, Private Bag X20, Hatfield, Pretoria, 0028, South Africa

${ }^{7}$ Panthera, New York, U.S.A.

${ }^{8}$ WWF South Africa, PO Box 23273, Claremont, 7735, Cape Town, South Africa

${ }^{9}$ Independent, PostNet Suite 340, Private Bag X1005, Claremont 7735, South Africa

\section{ABSTRACT}

African rhino populations are under severe threat from poachers, who kill rhinos to obtain horn for illegal trade. Over the 9-year period between 2008 and 2016, an estimated 7,124 rhinos were poached in Africa, with the main focus of this killing occurring in South Africa, where 1,054 rhinos were killed during 2016 alone. The poaching continues at an unsustainable rate, despite the international trade ban on horn and numerous law enforcement interventions from range state countries. One strategy proposed to reduce the poaching is the implementation of a legal international trade in rhino horn through the sustainable collection and sale of horn. This idea is controversial and has divided governments and conservationists worldwide, with one of the main concerns being that there may not be enough horn to satisfy the markets. Although the idea of trade is not new, there are no published estimates of how much horn could be provided on a sustainable basis. Based on recent rhino population estimates and feedback from private rhino owners, we estimate the annual potential supply of horn that could be obtained within South Africa from four sources: natural mortalities, dehorning, trophy hunting and stockpiled horn. Using different scenarios of horn production we show that the mass of horn that could be obtained varies from 5,319-13,356 kg per year.

Key words: rhino; horn; trade; poaching; dehorning; stockpiles 


\section{INTRODUCTION}

For most of the $20^{\text {th }}$ Century, many African rhino populations were in decline, mainly due to excessive hunting, habitat loss and poaching (Emslie, 2012a). From 1960 to 1995, a wave of poaching swept through Africa (with the exception of South Africa), reducing black rhino (Diceros bicornis) populations from an estimated 100,000 individuals to 2,400 (Emslie, 2012a). After 1995, poaching levels declined for about a decade and this allowed black rhinos to recover to a global population of 5,250 in December 2015 (Emslie et al., 2016). The northern subspecies of white rhino (Ceratotherium simum cottoni), which had already been reduced to a global population of 2,360 by 1960 , has been less fortunate and is currently on the brink of extinction (Emslie, 2012b).

In contrast, South African populations of black and white rhinos (subspecies C. s. simum), both of which had been nearly extinct in the year 1900 due to uncontrolled hunting, grew in numbers over the last 100 years and were not exposed to the same high levels of poaching seen in countries to the north. In fact, the recovery of the white rhino in South Africa has been described as one of the most remarkable conservation success stories of the last century (Wilson and Mittermeier, 2011).

However, a massive recent increase in rhino poaching across Africa, and particularly in South Africa, is placing this achievement under threat. The illegal trade in rhino horn is one of the most pervasive criminal activities faced by The Convention on International Trade in Endangered Species of Wild Fauna and Flora (CITES) (CITES, 2012), and is driving the latest ongoing poaching crisis that resulted in at least 7,124 rhinos being killed across Africa over a 9-year period between 2008 and 2016 (data provided by the African Rhino Specialist Group, AfRSG). South Africa has been the worst affected country during this latest wave of poaching, with at least 6,102 rhinos poached during this period, of which 1,054 were killed during 2016 alone (figures released by the South African Department of Environmental Affairs (DEA)).

The increase in poaching since 2008 occurred despite an international ban on commercial trade in African rhino horn, which has been in place since 1977 (Emslie, 2012b), and numerous law enforcement measures implemented in South Africa since the increase in poaching started (Emslie, 2013; Emslie et al., 2013; Knight, 2016; Rademeyer, 2016). Antipoaching security is a vital component in the fight against illegal trade in rhino horn, and may have been responsible for the levelling-off of poaching in South Africa since the end of 2014 , but it has not yet been sufficient to prevent the high rates of killing. As a result of this, there have been calls from some segments of the conservation community to establish a legal international market for trading rhino horn (Biggs et al., 2013). The aim of this proposed trade would be to attract buyers away from the illegal market and provide much needed additional income to bolster security by investing a percentage of the revenue obtained from trade back into conservation (Biggs et al., 2013). This would be especially pertinent for private owners of white rhinos, who would be able to recuperate some of their anti-poaching costs through the sale of horn. At present, some private owners are selling their rhinos due to the prohibitive financial and security pressures resulting from the poaching, while others are moving their animals to neighbouring countries (Emslie et al., 
2016; Knight, 2016). Many of the white rhinos being sold are going to other private owners within South Africa, however, and the overall numbers on private land are still increasing (Emslie et al., 2016; Knight, 2016). This might in fact be beneficial for white rhinos on private land if the new owners consolidate their animals into larger breeding groups on bettermanaged properties with higher levels of security, because this would likely have positive genetic, demographic and anti-poaching outcomes.

Legal trade is a controversial idea, with some authors cautioning that trade will only be effective as a conservation tool under certain circumstances (Fischer, 2004) and others challenging the supposed assumptions underpinning the argument for trade (Nadal and Aguayo, 2014). One such assumption is that legalising trade will have no expansionary effect on demand (Fischer, 2004); if this is incorrect, legalising trade may increase the amount of horn needed to meet the demand at constant prices. This is an important consideration because the supply of horn is finite, but there is currently no objective estimate for the amount of horn that could be supplied on a sustainable basis.

At present, there is limited international support for legalising international trade in rhino horn, with the CITES Conference of Parties 17 (CoP17) (Johannesburg, South Africa 2016) rejecting a proposal by Swaziland to allow a limited regulated trade from their stockpiles (CITES, 2016). However, recent developments in South Africa around domestic trade in horn may change the dynamics of illegal trade, making it even more important to know how much horn is available from legitimate sources. Within South Africa, there has been a moratorium on domestic trade in rhino horn since 2009 (Government Gazette No. 31899, Notice No. 148, 13 February 2009), which has prohibited any sale of horn within the country. This has recently changed following a legal challenge that found the moratorium to be unconstitutional and the government is now obliged to allow the sale of rhino horn within the borders of South Africa. In an attempt to control the domestic trade, the government has drafted regulations for public comment that include a clause allowing foreign nationals to buy horns within South Africa, and then export them as personal items. Although both the South African government and CITES Secretariat have stated that these regulations do not allow international trade in rhino horn for primarily commercial purposes (see https://cites.org/eng/news/Background issuance CITES permits export of rhinoceros horn 15032017; and https://www.environment.gov.za/mediarelease/ rhinohorn_domestictrade_gamerancher), it remains uncertain what the potential ramifications will be on international trade dynamics of rhino horn.

In this paper we estimate the potential supply of rhino horn that could be extracted sustainably from current rhino populations in South Africa for the period of one year, and compare this with the estimated mass of poached horn that may be entering the illegal market. We consider four potential sources of rhino horn and present different production scenarios that take into account uncertainties surrounding each of these sources. The sources of horn we consider are:

1) Horn derived from rhinos that die of natural causes;

2) Horn derived from living rhinos that are dehorned at intervals. Rhino horns regrow after dehorning (Kock and Atkinson, 1994; Rachlow and Berger, 1997), as long as they are cut without damaging the generative epidermis layer from which the horns grow, and thus can provide a renewable source of horn from live rhinos; 
3) Horn derived from trophy hunted rhinos. This would be a highly contentious method for obtaining horns but, given the likely change in regulations that will allow hunters to sell their horns within South Africa, we cannot rule out the possibility that trophy hunted rhino horns may also contribute to the pool of horn potentially available for trade; and

4) Horn derived from stockpiles currently held by state and private owners.

\section{METHODS}

For the calculations of horn mass, we were interested in estimating what could currently be obtained from existing rhino populations through the lens of a one-year "snapshot". The most recent complete estimates of South Africa's rhino populations come from December 2015 , so we based our calculations on this time-period. As all of the variables used to estimate horn production from rhinos have some degree of measurement error, we present various scenarios for each calculation using upper, middle and lower estimate bounds in an attempt to demonstrate the range of possible outcomes of horn production. We conducted a local sensitivity analysis, whereby we compared the estimates of horn production by varying one input variable at a time, while holding the other input variables at a constant central value. This allowed us to determine how changes in input variables, with differing levels of uncertainty, affected the overall estimate of horn production.

\subsection{Horn from natural mortalities}

Horn mass estimates for rhinos dying of natural causes were calculated separately for white and black rhinos, for two age categories (adult/sub-adult and calves), and for state and private populations, with the mass of horn obtainable from each subgroup being calculated using equation 1 . Subgroup totals were then summed to obtain the grand total.

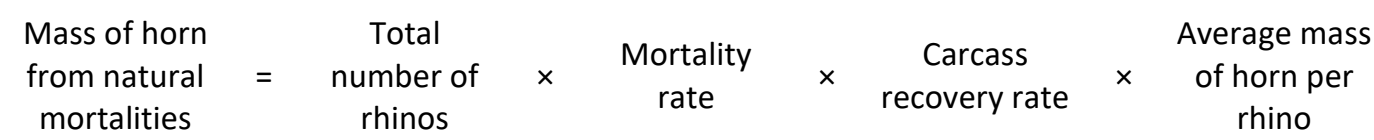

Estimates for each input variable, data sources, explanations and assumptions are explained in Table 1. For the sensitivity analysis, we varied four input variables: 1) rhino population sizes; 2) mortality rates; 3) carcass recovery rates; and 4) horn mass. The upper and lower bounds for these variables are outlined in Table 1.

Rhino species were subdivided into two age categories (adults/sub-adults and calves), but were not separated by sex. We did this because the largest available dataset for horn masses was collected from a random sample of mixed sex and mixed aged animals (excluding calves) that died naturally (Pienaar et al., 1991). We thus assumed that the average horn masses obtained from these data would be representative of the horns that could be obtained in future from natural mortalities within rhino populations. Additionally, there are no published datasets of horn masses obtained from natural mortalities where samples are separated by age. Horns obtained from rhinos that die naturally are more complete (and thus heavier) than horns obtained from dehorned rhinos because dehorning 
Table 1. Rhino population statistics, demographics, horn masses and assumptions used for estimating horn accumulation from natural mortalities in South Africa.

\begin{tabular}{|c|c|c|}
\hline Factor & Numbers & Data sources, notes and assumptions \\
\hline \multirow{4}{*}{$\begin{array}{l}\text { White rhino } \\
\text { numbers on } \\
\text { state land }\end{array}$} & $\begin{array}{l}\text { Total: } 12,599 \\
(12,153-13,042)\end{array}$ & $\begin{array}{l}\text { Total numbers (31 December 2015): Knight (2016) Upper and lower bounds based on 90\% bootstrapped confidence } \\
\text { intervals (AfRSG). For sensitivity analysis, we used these bounds. }\end{array}$ \\
\hline & $\begin{array}{l}\text { Adults/Sub-adults: } 9,827 \\
(9,479-10,173)\end{array}$ & $\begin{array}{l}\text { Age group proportions: Owen-Smith (1988). We defined calves as individuals }<3.5 \text { years old and adults as }>7 \text { years old } \\
\text { (as per African Rhino Specialist Group - AfRSG). }\end{array}$ \\
\hline & Calves: 2,772 & Age-group breakdown: Adults = 46\%; sub-adults = 32\%; calves $=22 \%$ \\
\hline & $(2,674-2,869)$ & \\
\hline \multirow{5}{*}{$\begin{array}{l}\text { White rhino } \\
\text { numbers on } \\
\text { private land }\end{array}$} & Total: 6,014 (5,801-6,226) & \multirow{5}{*}{$\begin{array}{l}\text { Total numbers ( } 31 \text { December 2015): Knight (2016). Upper and lower bounds based on 90\% bootstrapped confidence } \\
\text { intervals (AfRSG). } \\
\text { Age group proportions: Department of Environmental Affairs (Unpublished data). Adults=52\%; Sub-adults=29\%; } \\
\text { Calves=19\%. }\end{array}$} \\
\hline & Adults/Sub-adults: 4,871 & \\
\hline & $(4,699-5,043)$ & \\
\hline & Calves: 1,143 & \\
\hline & $(1,102-1,183)$ & \\
\hline \multirow{2}{*}{$\begin{array}{l}\text { White rhino } \\
\text { natural } \\
\text { mortality rates }\end{array}$} & $\begin{array}{l}\text { Adults/Sub-adults: } 2.1 \% \\
(1.9-2.3 \%)\end{array}$ & $\begin{array}{l}\text { Natural mortality rates: Owen-Smith (1988). These were from wild rhinos. We assumed that mortality rates are the } \\
\text { same on private land, but there are no data to confirm this. }\end{array}$ \\
\hline & Calves: $8.3 \%(7.5-9.1 \%)$ & For sensitivity analysis, we assumed that these mortality rates might vary by $10 \%$ (higher or lower). \\
\hline \multirow{2}{*}{$\begin{array}{l}\text { White rhino } \\
\text { carcass } \\
\text { recovery rate }\end{array}$} & State Land: 75\% (60-95\%) & \multirow[b]{2}{*}{$\begin{array}{l}\text { Carcass recovery rates: Ferreira et al. (2015). No work has been done to quantify the recovery rate of rhino carcasses } \\
\text { resulting from natural mortalities. However, Ferreira et al. (2015) estimated recovery rates of carcasses from poached } \\
\text { rhinos in the KNP between 2010-2013: they showed that an average of 63\% of carcasses were recovered within } 7 \\
\text { days of being poached, while 95\% (95\% Cl: } 92-98 \% \text { ) were recovered within two months. These recovery rates are } \\
\text { likely to be higher than recovery of carcasses from natural mortalities before the poaching crisis because the search } \\
\text { effort by SANParks has significantly increased in an attempt to counter the poaching (Sam Ferreira, SANParks, } \\
\text { personal communication). Recovery rates may drop off, therefore, if the poaching declines and if fewer resources are } \\
\text { allocated to finding carcasses, but we argue that, if state and private rhino owners have a financial incentive to locate } \\
\text { rhino carcasses to supply a legal trade of horn, they would be more likely to allocate resources to find dead animals. } \\
\text { Additionally, it is likely that un-retrieved rhino horn will remain intact and in a saleable condition for at least } 2 \text { months } \\
\text { after a rhino dies in the wild (Danie Pienaar, SANParks, personal communication), allowing up to 95\% horn recovery } \\
\text { under intensive search conditions. Furthermore, we predict that on private land, where many rhinos are monitored } \\
\text { individually, recovery rates are likely to be relatively high. Therefore, for recovery rates on state land, we assumed a } \\
\text { range from 60\% recovery (assuming low search effort) to } 95 \% \text { recovery (assuming high search effort). For recovery } \\
\text { rates on private land, we assumed a range from 75\% (assuming low search effort) to } 95 \% \text { (high search effort). }\end{array}$} \\
\hline & Pvt. Land: 85\% (75-95\%) & \\
\hline
\end{tabular}




\begin{tabular}{|c|c|c|}
\hline Factor & Numbers & Data sources, notes and assumptions \\
\hline $\begin{array}{l}\text { White rhino } \\
\text { horn mass }\end{array}$ & $\begin{array}{l}\text { Adults \& juveniles (both } \\
\text { sexes): } 5.88 \mathrm{~kg}(5.3-6.5 \mathrm{~kg}) \\
\text { Calf: } 0.96 \mathrm{~kg}(0.86-1.06 \mathrm{~kg})\end{array}$ & $\begin{array}{l}\text { White rhino horn mass: Pienaar et al. (1991). The adult and juvenile horn sample used (average mass } 5.88 \mathrm{~kg} \text { ) } \\
\text { comprised } 205 \text { horn sets from both sexes which were collected randomly from natural mortalities in the Kruger } \\
\text { National Park, Hluhluwe-iMfolozi Game Reserve and provincial nature reserves in Limpopo and Mpumalanga. We } \\
\text { considered these to be the most representative natural mortality horn samples available from wild populations in } \\
\text { South Africa and, therefore, the most representative of horns that would be collected from state owned rhino } \\
\text { populations in the future. As a result, we did not attempt to separate out male and female horn masses for state } \\
\text { protected areas, but instead used this mixed sex estimate. There are no published horn mass data from rhinos that } \\
\text { die naturally on private land, so we assumed the same average horn mass would be obtained from natural mortalities. } \\
\text { Calf horn mass is not documented from calves dying of natural causes, so we used horn mass data from } 602 \text { dehorned } \\
\text { calves between the ages of } 1 \text { and } 3 \text { years age provided by a private rhino breeder. For sensitivity analysis, we assumed } \\
\text { that these horn masses might vary by } 10 \% \text { (higher or lower). }\end{array}$ \\
\hline $\begin{array}{l}\text { Number of } \\
\text { black rhinos on } \\
\text { state land }\end{array}$ & $\begin{array}{l}\text { Total: } 1,382(1,319-1,444) \\
\text { Adults/Sub-adults: } 1,023 \\
\text { (976-1,069) } \\
\text { Calves: } 359(343-375)\end{array}$ & $\begin{array}{l}\text { Total numbers (31 December 2015): Knight (2016). Upper and lower bounds based on } 90 \% \text { bootstrapped confidence } \\
\text { intervals (AfRSG). } \\
\text { Age group proportions: Ferreira et al. (2011). We defined calves as individuals <3.5 years old (as per AfRSG). } \\
\text { Age-group breakdown: Adults }=65 \% \text {; sub-adults }=9 \% \text {; calves }=26 \% \text {. }\end{array}$ \\
\hline $\begin{array}{l}\text { Number of } \\
\text { black rhinos on } \\
\text { private land }\end{array}$ & $\begin{array}{l}\text { Total: } 511(488-534) \\
\text { Adults/Sub-adults: } 378 \\
\text { (361-395) } \\
\text { Calves: } 133(127-139)\end{array}$ & $\begin{array}{l}\text { Total numbers ( } 31 \text { December 2015): Knight (2016). Upper and lower bounds based on } 90 \% \text { bootstrapped confidence } \\
\text { intervals (AfRSG). } \\
\text { It is assumed that the demographic proportions are the same as black rhinos on state land but this is not based on } \\
\text { empirical data. }\end{array}$ \\
\hline $\begin{array}{l}\text { Black rhino } \\
\text { natural } \\
\text { mortality rates }\end{array}$ & $\begin{array}{l}\text { Adults: } 1 \% \\
\text { Sub-adults: } 18-36 \% \\
\text { Calves: } 1-6 \%\end{array}$ & $\begin{array}{l}\text { Natural mortality rates: Ferreira et al. (2011). } \\
\text { Black rhinos in Kruger National Park: Calves: } 1-6 \% \text { mortality, sub-adults: } 18-36 \% \text { mortality, adults: } 1 \% \text { mortality. } \\
\text { Because there are no data specifically for horn masses of sub-adult rhinos (see below), we combined mortality rates } \\
\text { for sub-adults and adults in the following way: Adults make up } 65 \% \text { of the population, while sub-adults make up } 9 \% \text {. } \\
\text { For the lower sub-adult mortality rate of } 18 \% \text {, the average mortality for adults and sub-adults combined was } 3.1 \% \\
([65 / 74 * 1)+[9 / 74 * 18]) \text {; for the higher sub-adult mortality rate of } 36 \% \text {, the average mortality for adults and sub-adults } \\
\text { combined was } 5.3 \%([65 / 74 * 1)+[9 / 74 * 36]) \text {. }\end{array}$ \\
\hline $\begin{array}{l}\text { Black rhino } \\
\text { carcass } \\
\text { recovery rate }\end{array}$ & $\begin{array}{l}\text { Same as white rhino } \\
\text { State Land: 60-95\% } \\
\text { Pvt. Land: } 75-95 \%\end{array}$ & Carcass recovery rates: Ferreira et al. 2015. See notes for white rhino carcass recovery rate above. \\
\hline $\begin{array}{l}\text { Black rhino } \\
\text { horn mass }\end{array}$ & $\begin{array}{l}\text { Adult/sub-adult sample: } \\
2.65 \mathrm{~kg} \\
\text { Calf: } 0.5 \mathrm{~kg}\end{array}$ & $\begin{array}{l}\text { Black rhino horn mass: Pienaar et al. (1991). The adult/sub-adult horn sample comprised } 75 \text { horn sets from both } \\
\text { sexes, but unknown age categories. They were collected from the Kruger National Park and Hluhluwe-iMfolozi Game } \\
\text { Reserve. Calf horn mass is not documented, so we assumed a mass of } 0.5 \mathrm{~kg} \text {. It is assumed that the proportion of } \\
\text { horns in the sample is representative of horns that would be recovered from future natural mortalities. }\end{array}$ \\
\hline
\end{tabular}


leaves some of the horn behind. As a result, we used different mass values for horns collected from natural mortalities and dehorning.

\subsection{Horn from live rhinos}

Only privately owned white rhinos were considered viable for dehorning. Rhinos on state land were excluded because very few national or provincial parks dehorn their rhinos (e.g. Kruger National Park does not dehorn rhinos for anti-poaching purposes (Lindsey and Taylor, 2012)). Many state owned rhinos may be subject to a policy of non-intervention to allow natural ecological and evolutionary processes to take place. Although it is feasible that state protected areas might dehorn to sell in future, there is currently no uniform government policy regarding this. Black rhinos were excluded because we assumed regular dehorning would be confined to white rhinos, which are easier to immobilise safely and which currently occur in much greater numbers.

To estimate potential horn mass production from dehorning, we collected data on two key variables: 1) the number of white rhinos available for dehorning on private land; and 2) the average annual horn growth (in mass) for these rhinos.

To estimate how many white rhinos were available for dehorning, it was necessary to know the total population size and demographics of white rhinos on private land, and the proportion of these animals that would be dehorned for trade. We used three estimates of population size based on lower, middle and upper bounds calculated using $90 \%$ bootstrapped confidence intervals (Table 2, data from AfRSG). For age and sex structure we used demographic data from two sources: the largest captive breeding operation (John Hume, unpublished data) and the Southern African Development Community Rhino Management Group (SADC RMG).

To estimate the proportion of white rhinos that would be dehorned for trade, we used the results of two recent surveys that assessed the views of private rhino owners regarding the legalising of international trade in horn. This is important because not all private rhino owners support legal trade, while not all those who support trade would want to dehorn their animals (e.g. landowners who run ecotourism operations may prefer to leave the horns on their rhinos).

A 2012 survey of 51 private rhino owners found that $86 \%$ would sell horn if international trade were legalised, while $65 \%$ would actively dehorn their rhinos in order to sell horn (Taylor et al., 2014). By comparison, a 2014 survey of 171 private rhino owners conducted under the auspices of the SADC RMG and funded by the DEA, showed that $84 \%$ supported legal international trade in horn, $80 \%$ would sell horn if it was legal to do so, while $44 \%$ would conduct intensive husbandry of rhinos in order to trade horn (Knight, 2016). In the second survey, landowners were not specifically asked if they would dehorn their rhinos to trade.

An additional consideration was whether the proportion of private rhino owners surveyed was equal to the proportion of rhinos they represented, a question not directly answered by either survey. Given the uncertainty in this variable, we calculated horn production using 
Table 2. Scenario data options for estimating the amount of rhino horn that could be obtained from dehorning white rhinos on private land.

\begin{tabular}{|c|c|c|c|c|c|c|c|}
\hline Input Variable & & & & Scenar & & & \\
\hline $\begin{array}{l}\text { Number of white rhinos on private land. } \\
\text { Upper and lower bounds based on } 90 \%\end{array}$ & Lower bound: & 5,80 & & & & & \\
\hline bootstrapped confidence intervals. Data & Middle bound: & 6,01 & & & & & \\
\hline & Upper bound: & 6,22 & & & & & \\
\hline White rhino demographics on private & Age group & & ario 1 & & & nario 2 & \\
\hline land. & & $M$ & $\mathrm{~F}$ & & M & $\mathrm{F}$ & \\
\hline Scenario 1: age and sex ratios estimated & $>30$ years & $1 \%$ & $2 \%$ & & $1 \%$ & $2 \%$ & \\
\hline from largest captive breeding operation. & $7-29$ years & $12 \%$ & 319 & & $20 \%$ & $29 \%$ & \\
\hline Data from John Hume. & 6 years & $4 \%$ & $4 \%$ & & $3 \%$ & $4.5 \%$ & \\
\hline Scenario 2: age and sex ratios estimated & 5 years & $4 \%$ & $5 \%$ & & $3 \%$ & $4.5 \%$ & \\
\hline from SADC RMG data, assuming sex ratio & 4 years & $5 \%$ & $5 \%$ & & $3 \%$ & $4.5 \%$ & \\
\hline $1 \mathrm{M}: 1.5 \mathrm{~F}$ & 3 years & $5 \%$ & $4 \%$ & & $3 \%$ & $4.5 \%$ & \\
\hline & 2 years & $5 \%$ & $4 \%$ & & $3.5 \%$ & $5.5 \%$ & \\
\hline & $\leq 2$ years & $5 \%$ & $4 \%$ & & $3.5 \%$ & $5.5 \%$ & \\
\hline $\begin{array}{l}\text { Percentage of white rhinos available for } \\
\text { dehorning on private land. Data from }\end{array}$ & DEA study: \% or & owners & would $\mathrm{k}$ & tensively & $55 \%$ & & \\
\hline Taylor et al. (2014) and DEA. & Taylor et al. : \% & of owne & ho woulc & & $71 \%$ & & \\
\hline & Weighted $\%$ of $\mathrm{c}$ & wners & support $i$ & ional tra & $84 \%$ & & \\
\hline White rhino horn growth rates (kg/year). & Age group & & & & & & \\
\hline Data from John Hume. Mass values for 2 & & M & $\mathrm{F}$ & M & $\mathrm{F}$ & M & $\mathrm{F}$ \\
\hline year old rhinos represent $1^{\text {st }}$ dehorning & $>30$ years & 0.805 & 0.489 & 0.776 & 0.477 & 0.836 & 0.502 \\
\hline mass (not growth rate). & $7-29$ years & 1.611 & 1.132 & 1.551 & 1.076 & 1.671 & 1.188 \\
\hline & 6 years & 1.390 & 1.143 & 1.248 & 1.029 & 1.531 & 1.258 \\
\hline & 5 years & 1.300 & 1.051 & 1.186 & 0.976 & 1.416 & 1.127 \\
\hline & 4 years & 1.128 & 0.809 & 1.043 & 0.759 & 1.212 & 0.858 \\
\hline & 3 years & 0.957 & 0.706 & 0.897 & 0.661 & 1.021 & 0.749 \\
\hline & 2 years & 0.971 & 0.651 & 0.909 & 0.602 & 1.033 & 0.699 \\
\hline
\end{tabular}


three proxies. For the lower limit we used results from the 2014 survey (Knight, 2016) that found $44 \%$ of owners would conduct intensive husbandry if trade were legalised. For an intermediate estimate we used results from the 2012 survey (Taylor et al., 2014) that found $65 \%$ would dehorn if trade were legalised. For the upper limit we calculated a weighted average of percentage of owners in both surveys who would sell rhino horn, taking into account the sample sizes of the two surveys. This weighted average was $81 \%$. We included this upper limit because the financial incentive to dehorn rhinos under legal trade conditions would be powerful, so it is possible that more owners who supported trade would be tempted to dehorn. For all three estimates, we also accounted for the fact that the largest single owner, who currently dehorns white rhinos and wishes to trade horn, had $\sim 21 \%$ of privately owned white rhinos at the end of 2015 , and we attributed all these rhinos to the dehorning group. Our final proxies were $55 \%, 71 \%$ and $84 \%$ for the lower, intermediate and upper limits of rhino owners who would dehorn.

To estimate the average annual growth rate of rhino horn, we used dehorning records from the largest captive breeding operation in South Africa. These records included the following data collected at each dehorning: 1 ) date of dehorning; 2) previous number of dehornings; 3) rhino sex; 4) rhino age (for rhinos born on the property, which represented about half the rhinos dehorned); and 5) mass of horn removed (the sum of the front and back horns as well as horn shavings). During each dehorning, horns were cut-off at similar heights above the growth point (commonly at a height of $80-100 \mathrm{~mm}$ ), but not at precisely the same point every time. This would have introduced some measurement error. The median age of first dehorning was 31 months for both sexes. In most cases, the time interval between consecutive dehorning of the same individuals varied from 1-2 years and, in some cases, animals that had been on the property the longest had been dehorned as many as six times over eight years. From these data of known age rhinos, we plotted horn mass growth rates against age for both sexes and estimated average horn growth rates for different aged rhinos.

For the purposes of our analyses, we separated out rhino horn growth rates into eight age categories (Table 2). Calves younger than 2 years were excluded, while rhinos of seven years and older were assigned the same horn growth rate because many of the adult rhinos in the sample data set were not born on the property and were of unknown age. It is thought that horn growth rates decline as rhinos age (John Hume, pers. com.), but there are few data to confirm this. To account for such declines we assumed that $3 \%$ of rhinos were older than 30 years (based on black rhino data provided by SADC RMG) and that horn growth rates in these old rhinos were half the normal adult growth rates. We based this estimate on the opinion of the major rhino breeder.

We also considered the possibility that repeated dehorning might reduce horn growth rates in individual rhinos, which could lead to declines in horn production with consecutive dehorning over time. To assess this, we plotted horn growth rates of adult white rhinos against the number of times rhinos were dehorned.

Total horn production from dehorning white rhinos on private land was estimated by summing the horn mass production from dehorning the different age group categories (separated by sex), then multiplying the total by the percentage of rhinos on private land available for dehorning (based on the three proxies of rhino owner views described above). 
For the sensitivity analysis, we varied four input variables: 1) private white rhino population size; 2) rhino age and sex ratios; 3 ) the percentage of owners who would dehorn; and 4) horn growth rates. The upper and lower bounds for these variables are outlined in Table 2.

\subsection{Horn from trophy hunted rhinos}

The average number of white rhinos hunted annually for trophies in South Africa between 2013 and 2015 was 78, while the average number of black rhinos hunted was three (Emslie et al., 2016). To estimate the total potential amount of horn available from these animals, we multiplied these numbers by the average horn mass of adult male rhinos, which we assumed would be the rhino demographic selected for hunting. Pienaar et al. (1991) estimated the average horn mass for adult male white rhinos to be $8.31 \mathrm{~kg}$, but did not differentiate between male and female adult black rhinos. Thus, we use the average for both sexes $(2.65 \mathrm{~kg})$, but recognise that this value is low. There is no estimate, however, for how many trophy hunters would sell the horns of the rhinos they hunt, so we present three scenarios.

\subsection{Potential quantities of stockpiled horn}

We estimated the potential mass of horns held in stockpiles using data from Knight (2016) and the AfRSG. It is uncertain how much of the stockpiled horn is in a suitable condition for sale to horn markets because stored horn is prone to degradation through insect damage. We present estimates of horn mass availability from stockpiles based on $50 \%, 70 \%$ and $90 \%$ suitability and under two scenarios where the stockpiles would be subject to drawdowns over five or ten-year periods.

\subsection{Horn currently entering the illegal market}

The average annual mass of horns currently entering the illegal market through poaching was calculated using equation 2 :

(2) Annual mass of horns entering the

illegal market

through poaching

(average for period 2014-2016)

$=\begin{gathered}\text { Annual number of } \\ \text { rhinos poached } \\ \text { across Africa } \\ \begin{array}{c}\text { (average for period } \\ \text { 2014-2016) }\end{array} \times \begin{array}{c}\text { \% of poached } \\ \text { horn reaching } \\ \text { illegal market }\end{array} \times \begin{array}{c}\text { Average mass of } \\ \text { horn from } \\ \text { poached rhinos }\end{array}\end{gathered}$

We based our estimate of the numbers of rhinos poached across Africa on statistics provided by the AfRSG. These are minimum estimates because they only record confirmed poaching incidents, and there are likely to be unrecorded and unreported poached animals (Emslie et al., 2016). The percentage of poached horn reaching the illegal market is not known, but Emslie et al. (2016) estimated that $76 \%$ of African rhino horns obtained from illegal sources between October 2012 and December 2015 were going into illegal trade. These illegal sources included horns from poached rhinos, horns stolen from natural mortalities, horn thefts from government stockpiles, horn thefts from other sources like privates stocks and museums, horns illegally sold from private stockpiles, and horns obtained from legal trophy hunts. The estimate of $76 \%$ of horn reaching illegal markets accounted for horn recoveries through seizures made by law enforcement within and outside Africa, as well as horns left behind by poachers and recovered from carcasses by 
rangers in the field. This latter situation arises when rhinos run away after being shot (only to die later), or when poachers are interrupted by rangers before they obtain the horns. It is important to note that this $76 \%$ does not tell us very much about who the buyers of rhino horn are and whether the horn is being consumed immediately, converted into durable artefacts or being stockpiled for future consumption. Our estimates do not include Asian rhinos as a source of horn entering the illegal market.

\section{RESULTS}

\subsection{Horn from natural mortalities}

Based on December 2015 rhino population estimates on state and private land, the estimated mass of horn that could be recovered in one year from rhinos that die naturally in South Africa ranged between 1,143-2,762 kg (Table 3).

The sensitivity analysis highlighted uncertainty around horn recovery and indicated that possible variation in population size led to horn production estimates $4 \%$ higher or lower than the middle estimate, while potential variation in mortality rates led to horn production estimates $11 \%$ higher or lower than the middle estimate (Table 3 ). Potential variation in carcass recovery rates led to horn production estimates $22 \%$ higher and $17 \%$ lower than the middle estimate, while potential variation in horn mass led to horn production estimates $10 \%$ higher or lower than the middle estimate.

\subsection{Horn from live rhinos}

Horn growth rates (increase in mass) varied with age of the rhino, and followed a nonlinear, asymptotic relationship in both sexes (Figure 1). In males, there was a linear increase in growth rate up to the age of $\sim 7$ years, after which growth rate levelled off, reaching an average of $1.611 \mathrm{~kg} /$ year (95\% Cl: $1.551-1.671 \mathrm{~kg} /$ year) at the age of $\sim 9$ years (Table 2$)$. In females, there was a linear increase in growth rate up to the age of $\sim 6$ years, after which growth rate levelled off, reaching an average of $1.132 \mathrm{~kg} /$ year $(95 \% \mathrm{Cl}: 1.076-1.188 \mathrm{~kg} /$ year) by the age of $\sim 7$ years.

Overall, the predicted mass of horn that could be recovered in one year from dehorning live white rhinos in South Africa varied between 3,023-5,788 kg (Table 4). The sensitivity analysis highlighted uncertainty around horn production and indicated that possible variation in population size led to horn production estimates $4 \%$ higher or lower than the middle estimate, while potential variation in age and sex ratios resulted in a $4 \%$ difference between higher and lower estimates (Table 4). Potential variation in the number of rhinos available for dehorning (based on owner attitudes towards trade) led to horn production estimates $18 \%$ higher and $23 \%$ lower than the middle estimate, while potential variation in horn growth rates led to horn production estimates $6 \%$ higher and $6 \%$ lower than the middle estimate. 


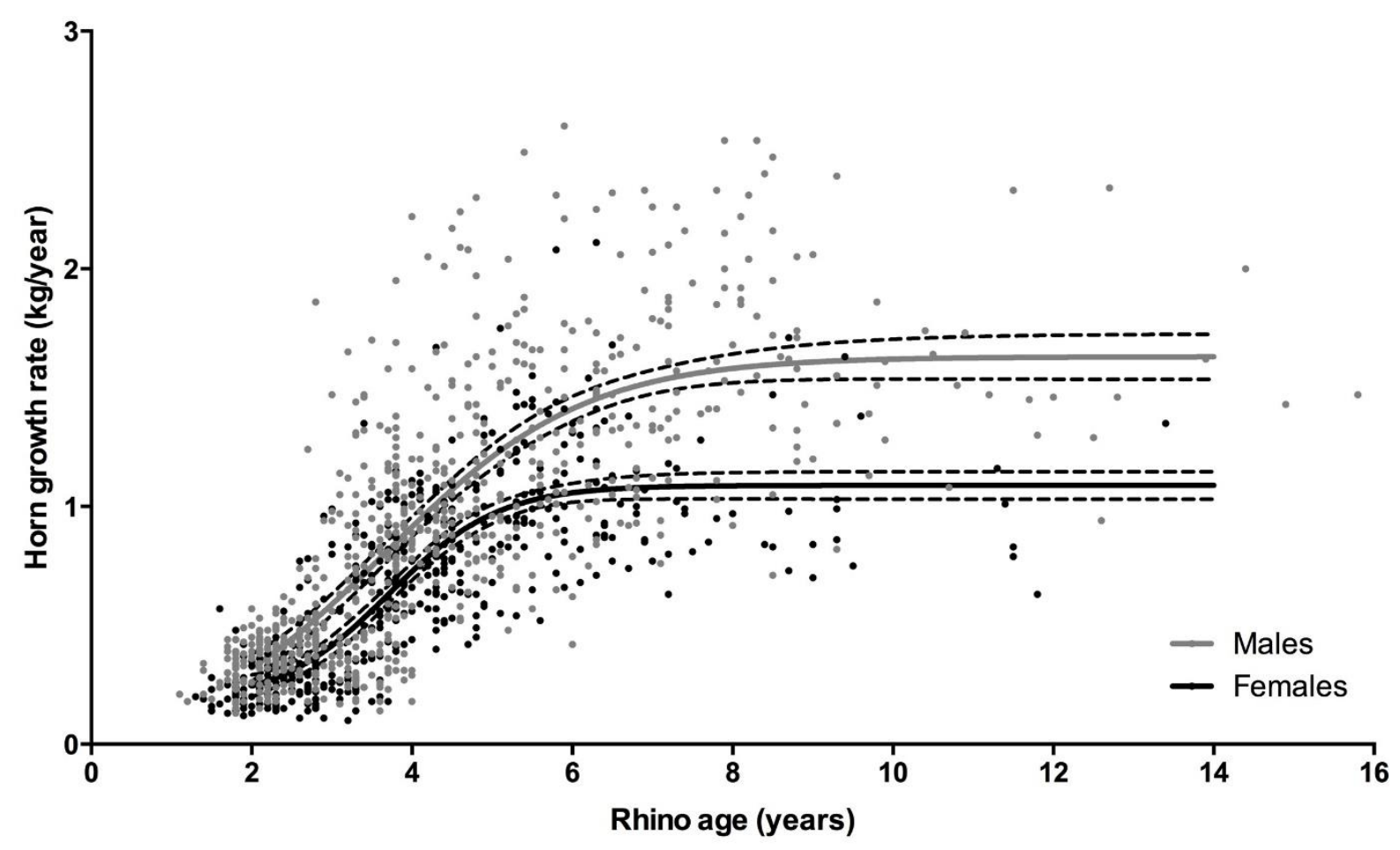

Figure 1. Horn growth rates for male and female white rhinos of known age measured during dehorning by one private rhino breeder (data provided by John Hume). Solid lines show non-linear, sigmoidal best-fit curves. Dashed lines represent $95 \% \mathrm{Cl}$. Sample size: males = 303 individuals, 705 measurements; females $=203$ individuals, 488 measurements. 
Table 3. Local sensitivity analysis for the range of possible horn production outcomes from natural mortalities. Input variables were changed one at a time while holding all the other input variables at a constant middle value (e.g. rhino population size was varied while holding mortality rates, recovery rates and horn mass constant). Middle, maximum and minimum values of horn production are also presented.

\begin{tabular}{|c|c|c|c|c|c|c|}
\hline $\begin{array}{l}\text { Input variable } \\
\text { changed }\end{array}$ & $\begin{array}{l}\text { Population } \\
\text { estimates }^{1}\end{array}$ & Mortality rates ${ }^{2}$ & Recovery rates ${ }^{3}$ & Horn mass ${ }^{4}$ & $\begin{array}{c}\text { Total horn } \\
\text { production for one } \\
\text { year }(\mathrm{kg})\end{array}$ & $\begin{array}{c}\text { Percentage } \\
\text { difference between } \\
\text { low and middle and } \\
\text { high and middle } \\
\text { estimates }\end{array}$ \\
\hline All middle & Middle & Middle & Middle & Middle & 1,792 & $-36 \%$ \\
\hline All low & Low & Low & Low & Low & 1,143 & \\
\hline All high & High & High & High & High & 2,762 & $+54 \%$ \\
\hline Rhino & Low & Middle & Middle & Middle & 1,727 & $-4 \%$ \\
\hline population & Middle & Middle & Middle & Middle & 1,792 & \\
\hline size & High & Middle & Middle & Middle & 1,857 & $+4 \%$ \\
\hline \multirow{3}{*}{$\begin{array}{l}\text { Mortality } \\
\text { rates }\end{array}$} & Middle & Low & Middle & Middle & 1,589 & $-11 \%$ \\
\hline & Middle & Middle & Middle & Middle & 1,792 & \\
\hline & Middle & High & Middle & Middle & 1,995 & $+11 \%$ \\
\hline \multirow{3}{*}{$\begin{array}{l}\text { Recovery } \\
\text { rates }\end{array}$} & Middle & Middle & Low & Middle & 1,485 & $-17 \%$ \\
\hline & Middle & Middle & Middle & Middle & 1,792 & \\
\hline & Middle & Middle & High & Middle & 2,177 & $+22 \%$ \\
\hline Horn & Middle & Middle & Middle & Low & 1,613 & $-10 \%$ \\
\hline \multirow[t]{2}{*}{ mass } & Middle & Middle & Middle & Middle & 1,792 & \\
\hline & Middle & Middle & Middle & High & 1,971 & $+10 \%$ \\
\hline
\end{tabular}

${ }^{1}$ Low, middle and high populations bounds based on $90 \%$ bootstrapped confidence intervals (data from AfRSG); ${ }^{2}$ Middle mortality rates based on Owen-Smith (1988), with high and low estimates assuming $10 \%$ variation either side of the middle value; ${ }^{3}$ Recovery rates based on Ferreira et al. (2015); ${ }^{4}$ Middle horn mass taken from Pienaar et al. (1991). 
Table 4. Local sensitivity analysis for range of possible horn production outcomes from dehorning white rhinos on private land. Input variables were changed one at a time while holding all the other input variables at a constant middle value (e.g. rhino population size was varied while holding demographics, \% rhinos available and horn growth rates constant). Middle, maximum and minimum values of horn production are also presented.

\begin{tabular}{|c|c|c|c|c|c|c|}
\hline $\begin{array}{c}\text { Input variable } \\
\text { changed }\end{array}$ & $\begin{array}{l}\text { Private rhino } \\
\text { population } \\
\text { estimates }^{1}\end{array}$ & Demographics $^{2}$ & $\begin{array}{l}\% \text { of rhinos } \\
\text { available for } \\
\text { dehorning }^{3}\end{array}$ & Horn growth rate ${ }^{4}$ & $\begin{array}{c}\text { Total horn } \\
\text { production for one } \\
\text { year }(\mathrm{kg})\end{array}$ & $\begin{array}{c}\text { Percentage } \\
\text { difference between } \\
\text { low and high } \\
\text { estimates }\end{array}$ \\
\hline Low & Low & Low & Low & Low & 3,023 & $-28 \%$ \\
\hline Middle & Middle & Low & Middle & Middle & 4,302 & \\
\hline High & High & High & High & High & 5,788 & $+35 \%$ \\
\hline Rhino & Low & Middle & Middle & Middle & 4,149 & $-4 \%$ \\
\hline population & Middle & Middle & Middle & Middle & 4,302 & \\
\hline size & High & Middle & Middle & Middle & 4,453 & $+4 \%$ \\
\hline \multirow[t]{2}{*}{ Demographics } & Middle & Low & Middle & Middle & 4,302 & $-4 \%$ \\
\hline & Middle & High & Middle & Middle & 4,476 & \\
\hline$\%$ rhinos & Middle & Middle & Low & Middle & 3,332 & $-23 \%$ \\
\hline available for & Middle & Middle & Middle & Middle & 4,302 & \\
\hline dehorning & Middle & Middle & High & Middle & 5,089 & $+18 \%$ \\
\hline Horn & Middle & Middle & Middle & Low & 4,046 & $-6 \%$ \\
\hline growth & Middle & Middle & Middle & Middle & 4,302 & \\
\hline rate & Middle & Middle & Middle & High & 4,558 & $+6 \%$ \\
\hline
\end{tabular}

${ }^{1}$ Low, middle and high populations bounds based on $90 \%$ bootstrapped confidence intervals (data from AfRSG); ${ }^{2}$ Age and sex ratios based on data from SADC RMG (representing the high outcome) and John Hume (representing the low outcome); ${ }^{3}$ Low, middle and high bounds based on private rhino owner views on trade; ${ }^{4}$ Low, middle and high bounds based on $95 \% \mathrm{Cl}$ horn growth rates taken from rhino breeder data. 


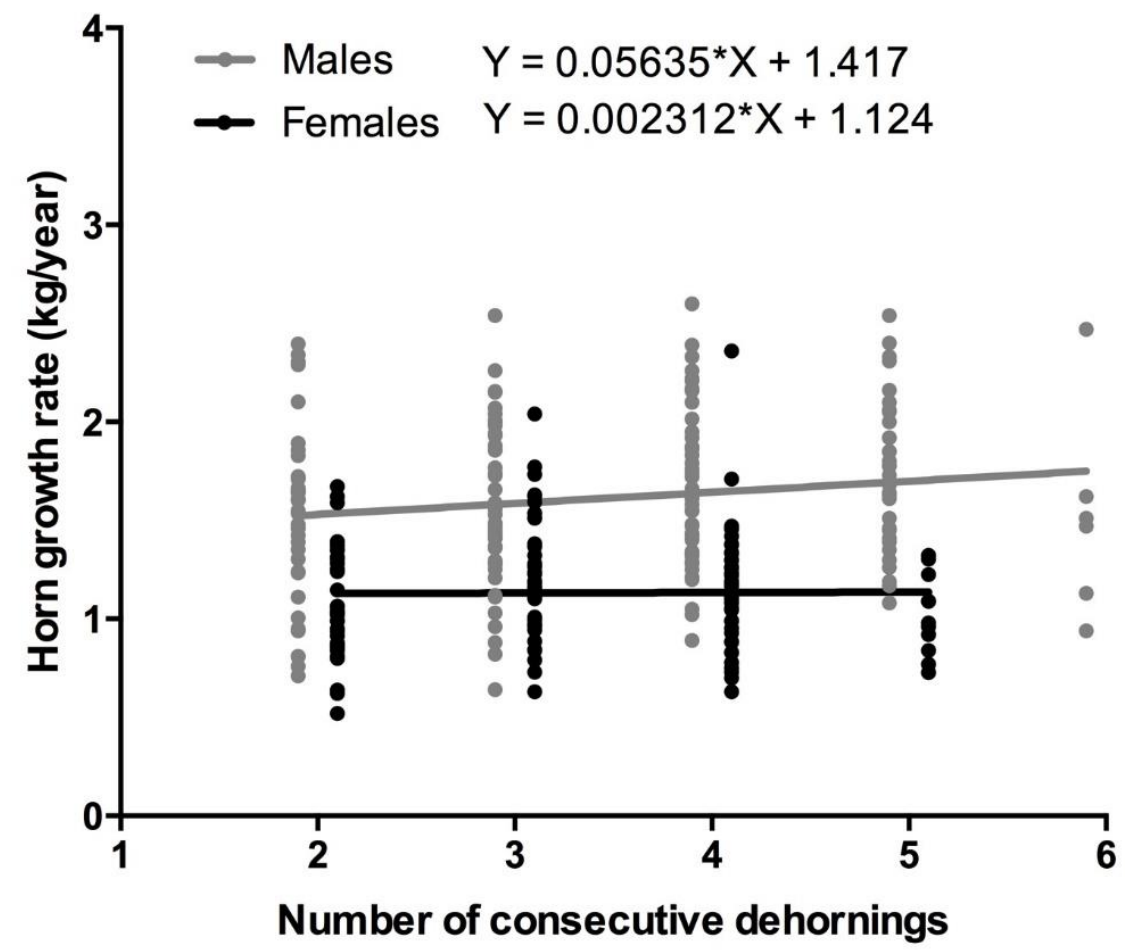

Figure 2. Horn growth rates vs number of consecutive dehorning events for adult white rhinos on private land. Data provided by John Hume. 
In adult male white rhinos, there was evidence of a slight increase in horn growth with additional consecutive dehorning events $(F=4.284, P=0.040)$, but no such evidence in females ( $F=0.006, P=0.937$ ) (Figure 2). The age of a rhino may confound the effect of consecutive dehorning on horn growth rate, but there is insufficient data for old rhinos to test this.

\subsection{Horn from trophy hunted rhinos}

The total mass of horn that could be obtained from trophy hunted rhinos over the period of one year is $648 \mathrm{~kg}$ from white rhinos and $8 \mathrm{~kg}$ from black rhinos.

\subsection{Horn from stockpiles}

For state owned stockpiles, the most recent available data regarding legal quantities (excluding unidentified horns confiscated from seizures) estimated $14601 \mathrm{~kg}$ in December 2012 (data supplied by AfRSG). These stockpiles have likely grown at 3\% per year (Mike Knight, AfRSG, personal communication), providing an estimated stockpile mass of $16434 \mathrm{~kg}$ at the end of 2016. For private stockpiles, Knight (2016) estimated 6,246 kg during 2014 , which equates to $6,626 \mathrm{~kg}$ if stockpiles have grown at $3 \%$ per year. The total amount of horn held in stockpiles in South Africa during 2016 was, therefore, $\sim 23,060 \mathrm{~kg}$. These stockpiles comprise a mixture of complete horns and pieces of horn.

Assuming lower and upper bounds of $50 \%$ and $90 \%$ horn suitability, the range of horn mass available from stockpiles would be between 2,306-4,150 kg/year over a five-year drawdown period, and 1,153-2,075 kg/year over a 10 -year drawdown period.

\subsection{Total annual horn production}

There are a large number of possible mass outcomes for horn production. The lowest likely annual production estimate, which assumes that trophy hunted horn is not included, is $5,319 \mathrm{~kg} / \mathrm{yr}$, while the highest likely production estimate, which includes trophy hunted horn, is 13,356 kg/yr (Figure 3). These estimates are equivalent to the horns carried by 9052,271 average adult/sub-adult white rhinos, with an average horn mass of $5.88 \mathrm{~kg}$.

\subsection{Horn currently entering the illegal market}

The average number of white rhinos poached annually across Africa from 2014-2016 was 1,130, while the average number of black rhinos poached over the same period was 147. Using the average horn mass for adult rhinos of mixed sex (Table 1), and under the assumption that $76 \%$ of poached horns were not intercepted by law enforcement, the mass of horn that is currently entering the black market in one year is $5,346 \mathrm{~kg}(5,050 \mathrm{~kg}$ for white rhino and $296 \mathrm{~kg}$ for black rhino). This is equivalent to the horns carried by 909 average adult/sub-adult white rhinos. 


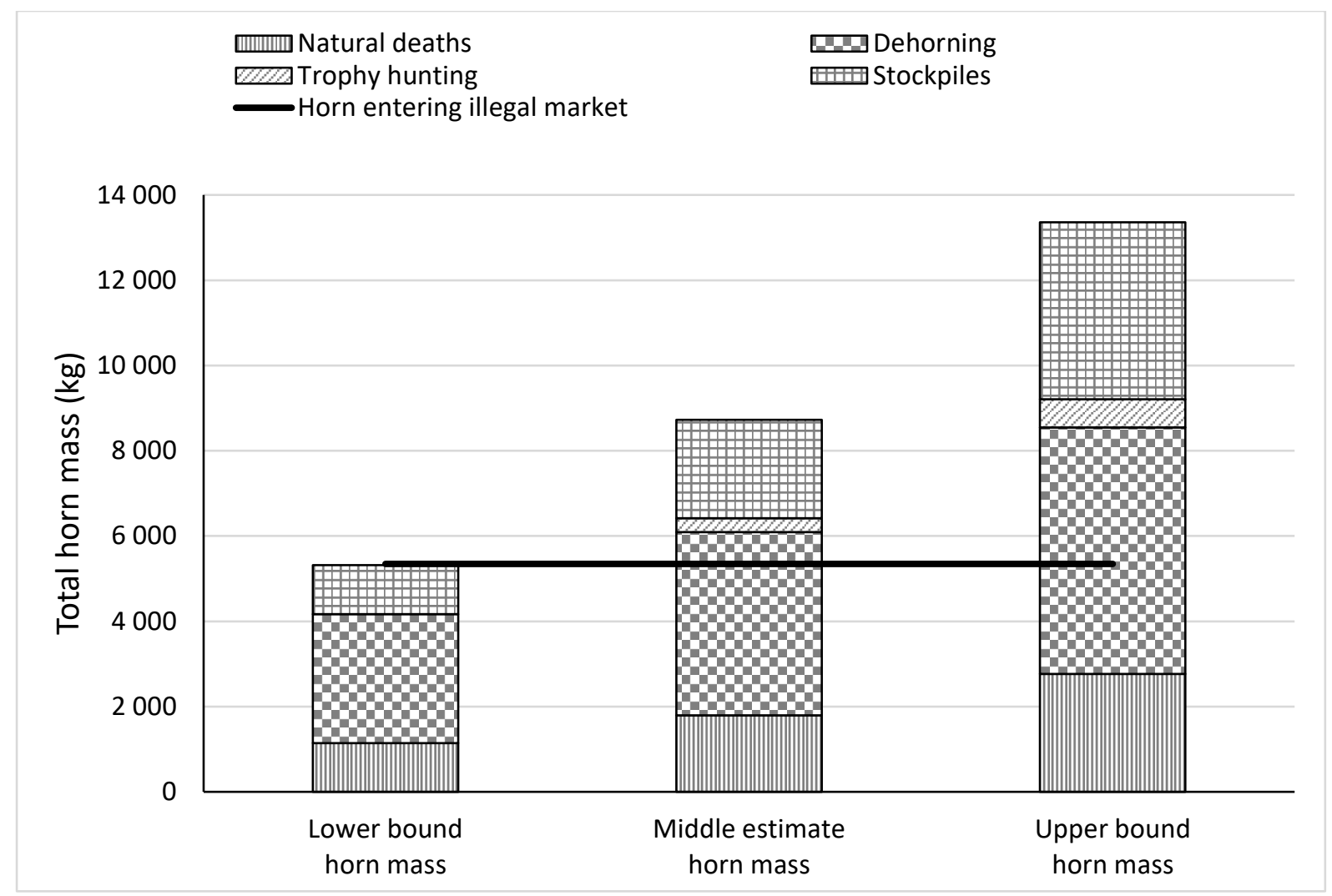

Figure 3. Lower, middle and upper estimates of total horn production in South Africa for the period of one year compared to the average amount of horn currently entering the illegal market (based on 2014-2016 data). 


\section{DISCUSSION}

We acknowledge certain limitations around our estimates due to insufficient knowledge about rhino ecology and population demography, thus we had to make assumptions about rhino populations as described in Tables 1 and 2. Additionally, although we estimated horn production from dehorning over the period of one year, it is possible that rhino owners would only dehorn every second or third year in order to avoid capturing rhinos as frequently and to provide time for horns to reach a larger size, potentially giving the horns a higher trading value per unit mass than smaller pieces of horn. Less frequent capture would reduce operational costs and reduce the risk of physical injury to rhinos during immobilisation, which can result if animals run into objects, fall badly or cannot be located after darting (Lindsey and Taylor, 2012). A potential negative impact of dehorning less frequently is that there is more horn left on the rhino to tempt poachers. Dehorning is not just about obtaining horn for future trade, but is used by some rhino owners as a method to reduce the risk of poaching under the assumption that there is less incentive for poachers. There is mixed evidence regarding whether dehorning is an effective method to reduce poaching (Lindsey and Taylor, 2012).

Our estimates represent the amount of horn that could be produced during a "snapshot" period of one year, given current rhino populations and management practices, but there are a number of reasons why these estimates might change over time if trade were legalised. Firstly, rhino populations are dynamic, and any changes in population size over time will affect the outcome of our estimates. Whether these changes are positive or negative will be partly dependent on the rate of poaching (which is unpredictable), future changes in management philosophies of rhino owners, and the availability of secure land with suitable habitat. Secondly, if trade is legalised, private rhino owners might tailor their operations to the financial opportunity, thus increasing the numbers of intensively bred rhinos and increasing horn production. This is already happening to a certain extent, even in the absence of legal international trade, because the number of rhinos on private land has increased in recent years (Knight, 2016), despite the fact that the overall rhino population in South Africa may have stopped growing (Knight, 2016). This may ultimately lead to a situation where "wild populations" become less common, with negative consequences for the conservation of wild rhinos. Thirdly, financial gains from trading horn would allow private intensive breeders to invest more in security, potentially displacing poaching pressure to state land. The latter would then face the decision of dehorning to generate revenues or losing the rest of their rhinos.

Under our lower limit of horn production, which included supplementing production through a drawdown on stockpiled horn over 10 years, there would be a deficit of $27 \mathrm{~kg}$, or the equivalent of five adult white rhinos, when compared to the mass of horn estimated to be currently entering the illegal market. Similarly, under our upper limit of horn production, which included supplementing production through a drawdown on stockpiled horn over five years, there would be a surplus.

Although the current extent of rhino horn demand could be inferred from the amount of horn entering the illegal market and limited reports of illegal price data, three significant unknowns remain, confounding attempts to estimate the extent of potential continued demand for horn (from both legal and illegal sources) under a future legal trading regime. 
The first is the current extent of (destructive) medicinal consumption versus non-destructive ornamental use and speculative stockpiling for future use. The second concerns the role of stigma, laundering and other effects considered by Fischer (2004), which could change along with legal status. The third concerns the price elasticity of demand for rhino horn, which will determine the extent to which additional supply of horn affects market prices. Adding horn supply under conditions of high demand elasticity may have a limited effect on illegal market prices and therefore poaching; conversely, with highly inelastic demand additional supply could lead to a dramatic drop in prices (and possible dumping of speculative stockpiles), thereby reducing the incentives for illegal activity. Although there have been some attempts to assess these factors (MacMillan et al., 2017), they remain largely unknown and are beyond the scope of this paper.

Any decision on legalising international commercial trade in rhino horn is currently under the control of CITES, and would require an amendment to the current annotated Appendix II listing that the white rhino falls under. Before any changes to the current status of rhinos can take place, the Convention will require a two-thirds majority vote in favour of change, and Parties to CITES would need strong evidence that a legal trade would not stimulate further rhino poaching in South Africa, or any other rhino range state. The current state of knowledge surrounding the possible impacts of a legal trade in rhino horn on supply chains and consumer demand is, however, very limited.

By estimating the potential mass of horn that South Africa could contribute sustainably to a legal rhino horn trade, we are providing just one piece of a large body of evidence that will be necessary to determine if legal trade is viable. We are not advocating for or against such a legal trade or making any inference on the risks to wild rhino populations from such a trade. Further research is necessary to assess the likely outcomes of legalising trade and how this might affect consumer demand.

\section{ACKNOWLEDGEMENTS}

In 2011, The South African Department of Environmental Affairs (DEA) commissioned the Endangered Wildlife Trust to conduct a study on the viability of legalising domestic trade in rhino horn within South Africa. DEA funded the research and we thank the department for its assistance during the project. We thank Mr John Hume for providing access to detailed data on horn growth rates in farmed white rhinos. We also thank Magdel Boshoff, Thea Carroll, Tony Conway, Elise Daffue, Richard Emslie, Pelham Jones, Michael Knight, Sonja Meintjies, Peter Novellie. The manuscript was improved by the inputs from three anonymous reviewers.

\section{REFERENCES}

Biggs, D., Courchamp, F., Martin, R., Possingham, H.P., 2013. Conservation. Legal trade of Africa's rhino horns. Science 339, 1038-1039.

CITES, 2016. Summary record of the fourteenth session of Committee I. Seventeenth meeting of the Conference of the Parties Johannesburg (South Africa), 24 September - 5 October 2016 (No. CoP17 Com. I Rec. 14 (Rev. 2)). Johannesburg, South Africa. 
CITES, 2012. Interpretation and Implementation of the Convention - Species Trade and Conservation: Rhinoceros, Report of the Secretariat. (No. SC62 Doc.47.2). CITES Secretariat, Geneva, Switzerland.

Emslie, R.H., 2013. African Rhinoceroses - Latest Trends in Rhino Numbers and Poaching (No. CoP16 Inf. 51). CITES Secretariat, Geneva, Switzerland.

Emslie, R.H., 2012a. Diceros bicornis: The IUCN Red List of Threatened Species. www.iucnredlist.org.

Emslie, R.H., 2012b. Ceratotherium simum. The IUCN Red List of Threatened Species. www.iucnredlist.org.

Emslie, R.H., Milliken, T., Talukdar, B., 2013. African and Asian Rhinoceroses - Status, Conservation and Trade (No. CoP16, Doc. 54.2 Annexe). CITES Secretariat, Geneva, Switzerland.

Emslie, R.H., Milliken, T., Talukdar, B., Ellis, S., Adcock, K., Knight, M.H., 2016. African and Asian Rhinoceroses - Status, Conservation and Trade: A report from the IUCN Species Survival Commission (IUCN SSC) African and Asian Rhino Specialist Groups and TRAFFIC to the CITES Secretariat pursuant to Resolution Conf. 9.14 (Rev. CoP15) (No. CoP17 Doc. 68). CITES Secretariat, Johannesburg, South Africa.

Ferreira, S.M., Greaver, C., Knight, G.A., Knight, M.H., Smit, I.P., Pienaar, D., 2015. Disruption of rhino demography by poachers may lead to population declines in Kruger National Park, South Africa. PloS One 10, e0127783.

Ferreira, S.M., Greaver, C.C., Knight, M.H., 2011. Assessing the Population Performance of the Black Rhinoceros in Kruger National Park. South Afr. J. Wildl. Res. 41, 192-204. doi:10.3957/056.041.0206

Fischer, C., 2004. The complex interactions of markets for endangered species products. J. Environ. Econ. Manag. 48, 926-953. doi:10.1016/j.jeem.2003.12.003

Knight, M.H., 2016. African Rhino Specialist Group Report. Pachyderm 57, 12-42.

Kock, M.D., Atkinson, M., 1994. Dehorning of Black (Diceros bicornis) and White Rhinoceros (Ceratotherium simum): the Zimbabwean experience., in: Proceedings of a Symposium on Rhinos as Game Ranch Animals. Onderstepoort, Pretoria, South Africa, pp. 42-47.

Lindsey, P.A., Taylor, W.A., 2012. A study on the dehorning of African rhinoceroses as a tool to reduce the risk of poaching. Department of Environmental Affairs, Pretoria, South Africa.

MacMillan, D., Bozzola, M., Hanley, N., Kasterine, A., Sheremet, O., 2017. Demand in Viet Nam for rhino horn used in traditional medicine. International Trade Centre, Geneva, Switzerland. 
Nadal, A., Aguayo, F., 2014. Leonardo's Sailors: A Review of the Economic Analysis of Wildlife Trade., LCSV Working Paper Series No. 6. University of Manchester.

Owen-Smith, N., 1988. Megaherbivores: The Influence of Very Large Body Size on Ecology. Cambridge University Press, Cambridge, UK.

Pienaar, D.J., Hall-Martin, A.J., Hitchins, P.M., 1991. Horn growth rates of free-ranging white and black rhinoceros. Koedoe 34, 97-105.

Rachlow, J.L., Berger, J., 1997. Conservation implications of patterns of horn regeneration in dehorned white rhinos. Conserv. Biol. 11, 84-91.

Rademeyer, J., 2016. Tipping point: Transnational organised crime and the war on poaching. Part 1 of a 2-part investigation into rhino horn trafficking in southern Africa. The Global Initiative Against Transnational Organized Crime.

Taylor, W.A., Brebner, K., Coetzee, R., Davies-Mostert, H.T., Lindsey, P.A., t'Sas-Rolfes, M., 2014. The viability of legalising trade in rhino horn in South Africa. Department of Environmental Affairs, Pretoria, South Africa.

Wilson, D.E., Mittermeier, R.A., 2011. Hoofed Mammals, Handbook of the Mammals of the World. Lynx Editions, Barcelona. 